\title{
Population Genetic Analysis of a Global Collection of Pyrenophora tritici-repentis, Causal Agent of Tan Spot of Wheat
}

\author{
T. L. Friesen, S. Ali, K. K. Klein, and J. B. Rasmussen
}

First author: U.S. Department of Agriculture-Agricultural Research Service (USDA-ARS), Cereal Crops Research Unit, Northern Crop Science Laboratory, Red River Valley Agricultural Research Center, Fargo, ND 58105; second and fourth authors: Department of Plant Pathology, North Dakota State University, Fargo 58105; and third author: Department of Biological Sciences, Minnesota State University, Mankato 56001.

Accepted for publication 19 May 2005.

\begin{abstract}
Friesen, T. L., Ali, S., Klein, K. K., and Rasmussen, J. B. 2005. Population genetic analysis of a global collection of Pyrenophora triticirepentis, causal agent of tan spot of wheat. Phytopathology 95:11441150.

The work presented here is the first major study to analyze the genetic diversity within the worldwide population of the economically important wheat pathogen Pyrenophora tritici-repentis. The genetic structure of field populations of $P$. tritici-repentis was determined using amplified

seven fungal isolates were collected from naturally infected wheat and wild grass species. The collection of $97 P$. tritici-repentis isolates included races 1, 2, 3, 4, 5, ND7, and ND8 and was collected from North America, South America, and Europe. Results show no genetic grouping of fungal races nor do results indicate grouping based on geographic location indicating that the population is preferentially outcrossing in nature and that the introduction and spread of this population is either relatively recent or that there has been a constant worldwide flow of this fungus possibly by seed movement between continents.
\end{abstract} fragment length polymorphism markers along with sequence data from the internal transcribed spacer region of the ribosomal DNA. Ninety-
Additional keywords: ascomycete, Drechslera tritici-repentis.
Pyrenophora tritici-repentis (anamorph, Drechslera triticirepentis), causal agent of tan spot of wheat, is an economically important pathogen in many wheat growing regions of the world. The fungus causing tan spot was first described in 1823 (17) and has since been found on all continents and in most major wheat growing regions of the world. This fungus was identified on grasses in Germany in 1902 (11) and described on Agropyron repens in the United States in 1923 (12) and on wheat in Japan in 1928 (28). After 1928 the fungus was reported as a saprophyte or a cause of minor spotting or occasionally as a cause of severe spotting in wheat growing regions throughout the world (17). In 1963, pink smudge of wheat seed was shown to be associated with the fungus causing yellow leaf spot (tan spot) of wheat (36) showing the potential for seed transmission of this fungus. In 1968 and 1969, tan spot was reported as severely pathogenic on wheat in North Dakota (16).

Hosford (16) proposed a disease cycle and a rating scale for disease and showed that wheat lines varied in resistance and isolates of the fungus varied in pathogenicity. Since this time, researchers have attempted to elucidate the mechanisms of the tan spot host-pathogen interactions. Lamari and Bernier (20) identified four pathotypes of $P$. tritici-repentis based on necrotic and chlorotic lesion production on wheat. Pathotype 1 produces both necrosis and chlorosis (nec+chl+), pathotype 2 produces necrosis only (nec+chl-), and pathotype 3 produces chlorosis only (nec-chl+). Pathotype 4 produces neither necrosis nor chlorosis (nec-chl-) and is nonpathogenic on wheat.

Corresponding author: T. L. Friesen; E-mail address: friesent@fargo.ars.usda.gov

DOI: $10.1094 /$ PHYTO-95-1144

This article is in the public domain and not copyrightable. It may be freely reprinted with customary crediting of the source. The American Phytopathological Society, 2005.
In 1995, Lamari et al. (21) described a second type of chlorosis that was identified based on a differential reaction where chlorosis was induced on wheat cv. Katepwa but not on cv. 6B365. This led them to propose a race classification system for $P$. tritici-repentis isolates. Isolates that produced necrosis on the differential cv. Glenlea and chlorosis on the differential line 6B365 but did not produce chlorosis on the differential cv. Katepwa were designated as race 1. Isolates that produced necrosis on Glenlea but did not produce chlorosis on 6B365 or Katepwa were designated as race 2 . Isolates that produced chlorosis on 6B365 but not Katepwa and did not produce necrosis on Glenlea were designated as race 3. Race 4 isolates are avirulent on wheat, and isolates designated as race 5 produced chlorosis on Katepwa but not on 6B365 and did not produce necrosis on Glenlea. Lamari et al. (22) documented the finding of the remaining combinations of symptoms that filled out a total of eight races. Race 6 combines virulence of races 3 and 5. Race 7 combines virulence of races 2 and 5 , and race 8 combines virulence of races 2,3 , and 5 .

Five toxins of $P$. tritici-repentis Ptr ToxA (33), Ptr ToxB (29), Ptr ToxC (13), and two different toxins simultaneously named Ptr ToxD $(24,26)$ have been reported. Ptr ToxA $(5,6,34,35,42)$ and Ptr ToxB $(25,32)$ have been the most well characterized. According to the proposed race classification system (22), Ptr ToxA is produced by races $1,2,7$, and $8 ; \mathrm{Ptr}$ ToxB is produced by races $5,6,7$, and 8; and Ptr ToxC is produced by races $1,3,6$, and 8 . The tan spot host-pathogen system has been the subject of recent reviews $(7,10,31)$.

P. tritici-repentis is a homothallic fungus that readily produces the sexual stage on field stubble giving the fungal population the opportunity for adaptation by sexual recombination. Previous to this study, little information was available on the genetic variation in the fungal population at the molecular level, especially between virulent and avirulent isolates. Therefore it was our goal to identify the extent of $P$. tritici-repentis population diversity. In this study, amplified fragment length polymorphisms (AFLPs) and 
ribosomal internal transcribed spacer (ITS) sequence analyses were used to evaluate $97 \mathrm{P}$. tritici-repentis isolates representative of races 1, 2, 3, 4, 5 (22), ND7 (26), and ND8 (2) and one isolate each from the closely related species $P$. teres and $P$. bromi. Isolates were recovered from wheat and non-cereal grasses and were collected from Europe, North America, and South America.

Lichter et al. (23) compared the electrophoretic karyotype of a limited number of pathogenic (race 1) and nonpathogenic (race 4) isolates. The chromosome containing ToxA, the gene coding for the production of Ptr ToxA (8), was most closely investigated. Although ToxA was absent from the nonpathogenic isolates investigated, other genomic regions of that chromosome in the pathogenic isolate were present on a single smaller chromosome in the nonpathogenic isolate and molecular markers (probes) for these genomic regions were not polymorphic. This led to the conclusion that there were substantial differences in chromosome composition between pathogenic and nonpathogenic isolates but that lack of molecular marker polymorphism indicated that the isolates could be closely related.

In the present study, our goal was to use a worldwide population of $P$. tritici-repentis to evaluate the level of genetic diversity within the natural population. This collection includes various races both pathogenic and nonpathogenic from different wheat growing areas of the world including regions of North America, South America, and Europe.

\section{MATERIALS AND METHODS}

P. tritici-repentis isolate collection. Ninety-seven isolates of $P$. tritici-repentis that had previously been race characterized (1, 2,3 , and 4) or were characterized for this study as described (1) along with control isolates of $P$. bromi and $P$. teres were evaluated. Collections made from 1969 to 2002 were obtained from North America, South America, and Europe (Table 1). Races 1, 2, 3, 4, 5 (21), ND7 (26), and ND8 (2) were used in this study. It should be pointed out that races $1,2,3,4$, and 5 are similar in reaction to those described by Lamari et al. (21), whereas races ND7 (26) and ND8 (2) were published simultaneously with races 7 and 8 described by Lamari et al. (22) and therefore do not have the same phenotype on the differential set. All isolates used in this study were single-spored at least twice to ensure genetic purity.

DNA isolation and polymerase chain reaction. For DNA extractions, 250-ml Erlenmeyer flasks containing $100 \mathrm{ml}$ of potato dextrose broth was inoculated with spores of each isolate and incubated at room temperature for $72 \mathrm{~h}$ in a rotary shaker at $100 \mathrm{rpm}$. Mycelium was filtered through Miracloth (Calbiochem Corporation, La Jolla, CA) and washed with sterile distilled water, harvested, and stored at $-20^{\circ} \mathrm{C}$ until ground. Mycelium was ground to a fine powder with liquid nitrogen and a mortar and pestle. Extraction of genomic DNA was done as described (3). ITS regions were amplified by polymerase chain reaction (PCR) using the ITS1 and ITS4 primers (38). Individual reactions included $200 \mu \mathrm{M}$ each dNTPs, $75 \mathrm{ng}$ each forward and reverse primers, 1 unit of $P f u$ proofreading polymerase (Stratagene, La Jolla, CA), and $40 \mathrm{ng}$ of genomic DNA in $1 \times P f u$ polymerase reaction buffer. All PCR was performed on a Dyad Thermal Cycler (MJ Research, Watertown, MA). The cycling parameters were 40 cycles of the following: denaturation, $60 \mathrm{~s}$ at $94^{\circ} \mathrm{C}$; annealing, $60 \mathrm{~s}$ at $55^{\circ} \mathrm{C}$; and extension, $3 \mathrm{~min}$ at $72^{\circ} \mathrm{C}$. PCR was visualized on a $1 \%$ agarose gel in a $1 \times$ Tris-borate-EDTA (TBE) running buffer. Two PCR reactions were performed for each isolate.

AFLP analysis. AFLP reactions were performed as described (37). All PCR was performed on a Dyad Thermal Cycler (MJ Research). Genomic DNA of each isolate was digested with EcoRI and MseI in $1 \times$ ligation buffer and ligated to AFLP adaptors (37) in one step for $4 \mathrm{~h}$ at $37^{\circ} \mathrm{C}$. The digested and ligated templates were diluted 1:10 before being used in the preamplification. Samples were preamplified using the following parameters: 20 cycles of $94^{\circ} \mathrm{C}$ for $30 \mathrm{~s}, 56^{\circ} \mathrm{C}$ for $60 \mathrm{~s}$, and $72^{\circ} \mathrm{C}$ for $60 \mathrm{~s}$. Following preamplification, the template was diluted 1:40 to be used in selective amplification. Selective amplification was completed using IR700 (LI-COR, Lincoln, NE) labeled EcoRI primers with a two base extension (either $\mathrm{AG}$ or $\mathrm{AC}$ ) and an unlabeled $\mathrm{Mse}$ I primer also with a two base extension (CA). Cycling parameters included one cycle of $94^{\circ} \mathrm{C}$ for $30 \mathrm{~s}, 65^{\circ} \mathrm{C}$ for $60 \mathrm{~s}$, and $72^{\circ} \mathrm{C}$ for $30 \mathrm{~s}$; this cycle was followed by 12 cycles in which the annealing temperature was lowered each cycle by $0.7^{\circ} \mathrm{C}$ from 65 to $56^{\circ} \mathrm{C}$. This was followed by 23 cycles of $94^{\circ} \mathrm{C}$ for $30 \mathrm{~s}$, and $56^{\circ} \mathrm{C}$ for $30 \mathrm{~s}$, and then held at $4^{\circ} \mathrm{C}$ indefinitely.

AFLP fragments were separated on a LI-COR Global Edition $\mathrm{IR}^{2}$ System (LI-COR) in a $6 \%$ polyacrylamide gel $(25 \mathrm{~cm}$ in length and $0.25 \mathrm{~mm}$ in thickness) made with $1 \times$ TBE buffer (LICOR). This $1 \times$ TBE was also used as the running buffer. One microliter of the AFLP reaction mixture was loaded into each well. The LI-COR 700-bp molecular weight standard (LI-COR) was loaded at the left and right lane of each gel. Electrophoresis was done on the Global IR $^{2}$ system (LI-COR) using IR700 labeled EcoRI primers. Parameters include voltage set at 2,000 V, current at $40 \mathrm{~mA}$, power at $50 \mathrm{~W}$, and temperature at $45^{\circ} \mathrm{C}$. Each gel was run for $2.5 \mathrm{~h}$. AFLP fragments were scored by hand and converted into numerical data (presence $=1$, absence $=0$ ). These coded data were combined over all AFLP bands within strains and used to define haplotypes. The coded haplotypes of these strains were then entered into the software PopGene (39) for analysis of linkage disequilibria, allele frequency, effective allele number, and genetic diversity index (Table 2). Only bands that gave an effective allele number of 1.20 or greater were used in the calculation of linkage disequilibria, due to the low sample size and consequent lack of statistical power.

DNA sequencing and sequence analysis. Amplified products were gel purified using the QIAquick Gel Extraction Kit (Qiagen Inc., Valencia, CA) followed by commercial sequencing using both forward and reverse primers (ITS1 and ITS4) for each of two independent PCRs. A single consensus sequence was generated from alignments of at least two reads for each of two PCRs for each isolate. If a consensus sequence was not obvious from the four sequence alignments, the PCR and sequencing was repeated.

Analysis of the ITS consensus sequences was done using ClustalW sequence analysis software (15), using the consensus sequences derived above coded into FASTA format (30). Output from ClustalX was coded into PHYLIP format (14) for phylogenetic analysis. Sequences derived in this study were compared with sequences in GenBank as follows: AF081446, AF071347, AF400889, AF400890, AF400891, AF400892, AF400893, AF400894, AF400895, AF400896, and AF163061 from P. teres; AF071348, AY004807, and AY004809 from P. bromi; and AF071348 and AY004808 from P. tritici-repentis.

\section{RESULTS}

The 99 strains displayed 61 AFLP haplotypes (Table 1). Of these, two belonged to species other than $P$. tritici-repentis ( $P$. bromi and $P$. teres) and were not used in the calculations of allelic frequency, number of effective alleles, or linkage disequilibria. The $P$. bromi and $P$. teres strains produced AFLP banding patterns with a high degree of similarity to those of $P$. tritici-repentis. One strain in particular, $P$. teres ND89-19, shares all but 5 of the 55 scored bands with P. tritici-repentis strain Ptr 2000-5. Of the 59 remaining haplotypes, 13 were found in more than one strain. Seventeen strains shared one haplotype, nine strains a second, four strains a third, and three shared a fourth, and the remaining shared haplotypes were found in two strains each. Fourty-six haplotypes were found only once each (Table 1). Analysis of linkage disequilibrium among those loci that showed a relatively high $(\geq 1.20)$ number of effective alleles revealed 10 pairs of loci that were in significant $(P<0.05)$ 
linkage disequilibrium out of a possible 66 pairs. The pairs of loci that were in disequilibrium were AG190 and AC364, AG190 and $\mathrm{AC} 355, \mathrm{AG} 190$ and $\mathrm{AC} 310, \mathrm{AC} 447$ and $\mathrm{AC} 326, \mathrm{AC} 447$ and $\mathrm{AC} 100, \mathrm{AC} 364$ and $\mathrm{AC} 355, \mathrm{AC} 364$ and $\mathrm{AC} 310, \mathrm{AC} 355$ and $\mathrm{AC} 310, \mathrm{AC} 326$ and $\mathrm{AC} 100$, and $\mathrm{AC} 310$ and $\mathrm{AC} 100$.

Accession numbers for ITS sequences are given in Table 1. Using the software within ClustalX, the sequences were aligned, and the output exported to PHYLIP. A dendrogram was constructed using maximum-likelihood. There was no strongly supported structure within the dendrogram, and only the sequences from $P$. teres were clearly separated from the sequences from the rest of the strains belonging to $P$. tritici-repentis and $P$. bromi. Therefore, the dendrogram was not included as a figure. The primary differences among sequences were the presence and absence of small deletions or additions.

\section{DISCUSSION}

We used AFLP to determine the level of diversity among these strains because it has been shown to accurately define gene loci (18). The level of diversity revealed by this technique in these strains of $P$. tritici-repentis is reasonably high. The number of effective alleles per locus (9) varies between 1 (monomorphic) and 1.7 (essentially dimorphic), with a large number of strains in our sample carrying unique alleles. This is also reflected in the contributions of the various loci to genetic diversity reflected by Nei's index (27) (Table 2). With a sample size of 97, we could expect to miss some low-frequency alleles altogether. We found four monomorphic (band always present) AFLP loci out of 50 loci scored for $P$. tritici-repentis. Five further loci were defined for either the $P$. teres or P. bromi strains used, but there was no corre-

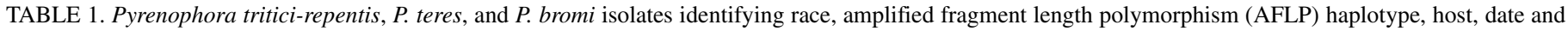
location of collection, and GenBank accession number

\begin{tabular}{|c|c|c|c|c|c|c|}
\hline Isolate & Race $^{\mathrm{a}}$ & AFLP type ${ }^{b}$ & $\begin{array}{l}\text { Host from which isolate } \\
\text { was collected }\end{array}$ & $\begin{array}{l}\text { Date of } \\
\text { collection }\end{array}$ & $\begin{array}{l}\text { Location of } \\
\text { collection }\end{array}$ & $\begin{array}{c}\text { GenBank ITS } \\
\text { accession number }\end{array}$ \\
\hline \multicolumn{7}{|l|}{ P. tritici-repentis } \\
\hline $86-124$ & 2 & $\mathrm{a}$ & Wheat & $1980 \mathrm{~s}$ & Canada & AY739849 \\
\hline SD 97038 & 1 & $\mathrm{a}$ & Wheat & 1997 & South Dakota & AY739782 \\
\hline AKARK B10 & 1 & $\mathrm{a}$ & Wheat & 2002 & Arkansas & AY739792 \\
\hline SDD2-5 & 1 & $\mathrm{a}$ & Durum & 1999 & South Dakota & AY739835 \\
\hline CZ021 & 3 & $\mathrm{a}$ & Wheat & 2000 & Czech Republic & AY739837 \\
\hline CZ012 & 1 & $\mathrm{a}$ & Wheat & 2000 & Czech Republic & AY739838 \\
\hline OK11 & 1 & $\mathrm{a}$ & Wheat & 1982 & Oklahoma & AY739839 \\
\hline $\mathrm{K} 2-2$ & 1 & $\mathrm{a}$ & Wheat & $1980 \mathrm{~s}$ & Kansas & AY739840 \\
\hline OK98-1-2 & 1 & $\mathrm{a}$ & Wheat & 1998 & Oklahoma & AY739842 \\
\hline PYD7 & 1 & $\mathrm{a}$ & Wheat & 1969 & North Dakota & AY739843 \\
\hline CZ60 & 1 & $\mathrm{a}$ & Wheat & 2000 & Czech Republic & AY739844 \\
\hline CZ1 & 1 & $\mathrm{a}$ & Wheat & 2000 & Czech Republic & AY739845 \\
\hline AK CR B1 & 1 & $\mathrm{a}$ & Wheat & 2002 & Arkansas & AY739860 \\
\hline AK Jac A1 & 1 & $\mathrm{a}$ & Wheat & 2002 & Arkansas & AY739847 \\
\hline ARD-3 & 1 & $\mathrm{a}$ & Wheat & 1998 & Argentina & AY739848 \\
\hline SD97017 & 1 & $\mathrm{a}$ & Wheat & 1997 & South Dakota & AY739850 \\
\hline K3-1 & 1 & $\mathrm{a}$ & Wheat & $1980 \mathrm{~s}$ & Kansas & AY739858 \\
\hline ASCI & 1 & $\mathrm{~b}$ & Wheat & $1980 \mathrm{~s}$ & Canada & AY739861 \\
\hline SD 4-2 & 1 & $\mathrm{~b}$ & Smooth brome grass & 1998 & South Dakota & AY739790 \\
\hline 98D-4-16 & 1 & $b$ & Durum & 1998 & North Dakota & AY739859 \\
\hline 98D-5-24 & 1 & $\mathrm{~b}$ & Durum & 1998 & North Dakota & AY739801 \\
\hline Ptr 92 119-2-3 & 1 & $\mathrm{~b}$ & Wheat & 1992 & North Dakota & AY739803 \\
\hline Ptr 11995 & 1 & $\mathrm{~b}$ & Wheat & 1995 & North Dakota & AY739806 \\
\hline W1 & 1 & $\mathrm{~b}$ & Durum & 1998 & North Dakota & AY739830 \\
\hline AK CR A1 & 1 & $\mathrm{~b}$ & Wheat & 2002 & Arkansas & AY739831 \\
\hline $1 / \mathrm{L} 1$ & 1 & $\mathrm{~b}$ & Wheat & 2002 & North Dakota & AY739833 \\
\hline 98D 1-1 & 1 & $\mathrm{c}$ & Durum & 1998 & North Dakota & AY739797 \\
\hline CZ033 & 1 & $\mathrm{c}$ & Wheat & 2000 & Czech Republic & AY739841 \\
\hline $98 D 25-3$ & 1 & $\mathrm{c}$ & Durum & 1998 & North Dakota & AY739851 \\
\hline $98-37-1$ & 1 & $\mathrm{c}$ & Wheat & 1998 & North Dakota & AY739852 \\
\hline DW5 & 5 & $\mathrm{~d}$ & Durum & 1998 & North Dakota & AY739784 \\
\hline AKPRA A1 & 1 & $\mathrm{~d}$ & Wheat & 2002 & Arkansas & AY739781 \\
\hline $98-33-28$ & 1 & $\mathrm{~d}$ & Wheat & 1998 & North Dakota & AY739796 \\
\hline BR25 & $\mathrm{ND}^{\mathrm{c}}$ & $\mathrm{e}$ & Wheat & 1999 & Brazil & AY739776 \\
\hline UR3 & 2 & $\mathrm{e}$ & Wheat & 1998 & Uruguay & AY739786 \\
\hline AK lon A5 & 1 & $\mathrm{f}$ & Wheat & 2002 & Arkansas & AY739787 \\
\hline AKPRA B1 & 1 & $\mathrm{f}$ & Wheat & 2002 & Arkansas & AY739826 \\
\hline BR11 & $\mathrm{ND}^{\mathrm{c}}$ & $\mathrm{g}$ & Wheat & 1999 & Brazil & AY739777 \\
\hline AK cros A1 & 1 & $\mathrm{~g}$ & Wheat & 2002 & Arkansas & AY739788 \\
\hline Akjac A5 & 1 & $\mathrm{~h}$ & Wheat & 2002 & Arkansas & AY739791 \\
\hline OXEN-1 Ptr & 1 & $\mathrm{~h}$ & Wheat & 2001 & North Dakota & AY739829 \\
\hline ARD 1 & $\mathrm{ND}^{\mathrm{c}}$ & $\mathrm{i}$ & Wheat & 1998 & Argentina & AY739794 \\
\hline $98 D-3-16$ & 1 & $\mathrm{i}$ & Durum & 1998 & North Dakota & AY739795 \\
\hline MD122 & 4 & $\mathrm{j}$ & Wild barley & 1997 & North Dakota & AY739809 \\
\hline MD155 & 4 & $\mathrm{j}$ & Smooth brome grass & 1997 & North Dakota & AY739810 \\
\hline AK Lon A1 & 1 & $\mathrm{k}$ & Wheat & 2002 & Arkansas & AY739827 \\
\hline TSR9-RB11-1 & 1 & $\mathrm{k}$ & Wheat & 1988 & North Dakota & AY739855 \\
\hline SY3-122 & 4 & 1 & Intermediate wheat grass & 1997 & North Dakota & AY739819 \\
\hline
\end{tabular}

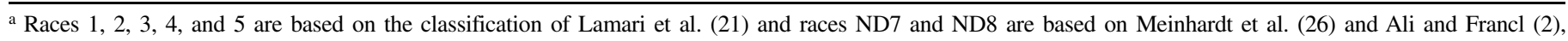
respectively.

b AFLP haplotypes are groups of isolates having identical AFLP marker patterns. Absence of a letter entry indicates a unique haplotype for that isolate.

c Published race designations $(2,25)$ not corresponding to the accepted race classification proposed by Lamari et al. (21). 
sponding band produced from DNA from any of the $P$. triticirepentis strains tested. Nevertheless, we find that the majority of the strains appear to belong to a single recombining population, as determined by gametic linkage equilibrium. Where there is linkage disequilibrium, this is probably due to relatively low sample sizes and the presence of a few strains that are atypical for the species. If one were to eliminate five strains (usda10a, wb1, wb4, wb5, and 93-9) from the sample, most of the linkage disequilibria would also be eliminated. These strains with linkage disequilibrium may well belong with the other strains in a recombining population, but the sample size is insufficient at this time to give a definitive answer. It is important to note that these strains did not come from geographically isolated regions, but were coincident in origin with the majority of the strains in the sample. Curiously, all of these strains were isolated from non-crop hosts (wild barley or wild rye). This is in contrast to the strains with diverse geographic origins, which were not differentiated from each other genetically.

The level of linkage equilibrium in the sample is surprising given that the sampled strains were not collected in a systematic manner and that $P$. tritici-repentis is homothallic. A priori we expected large interpopulational effects, and the effects of selfing, either of which could cause significant deviation from linkage equilibrium. That no such effects were found is further evidence that the strains studied were drawn from one large, stable, interbreeding population. This includes the strains isolated in the Czech Republic, which all had one of the more common haplotypes as did all but one of the strains isolated in South America. The Czech strains could have been introduced from North America, but it is likely that they are not of a single clone as four of the strains share the most common North American haplotype, and the fifth has the third most common North American haplotype.

TABLE 1. (Continued from preceding page)

\begin{tabular}{|c|c|c|c|c|c|c|}
\hline Isolate & Race $^{\mathrm{a}}$ & AFLP type ${ }^{b}$ & $\begin{array}{l}\text { Host from which isolate } \\
\text { was collected }\end{array}$ & $\begin{array}{l}\text { Date of } \\
\text { collection }\end{array}$ & $\begin{array}{l}\text { Location of } \\
\text { collection }\end{array}$ & $\begin{array}{c}\text { GenBank ITS } \\
\text { accession number }\end{array}$ \\
\hline NG18-8 & 4 & 1 & Intermediate wheat grass & 1997 & North Dakota & AY739820 \\
\hline Akcros A5 & 1 & $\mathrm{~m}$ & Wheat & 2002 & Arkansas & AY739832 \\
\hline OK6 & 1 & $\mathrm{~m}$ & Wheat & 1982 & Oklahoma & AY739857 \\
\hline Pti 2 & 1 & & Wheat & 1973 & South Dakota & AY739768 \\
\hline $331-9$ & 3 & & Durum & $1980 \mathrm{~s}$ & Canada & AY739836 \\
\hline $93-3$ & 4 & & Winter barley & 1998 & North Dakota & AY739824 \\
\hline $\mathrm{K} 1-3$ & 1 & & Wheat & $1980 \mathrm{~s}$ & Kansas & AY739766 \\
\hline OK12 & 1 & & Wheat & $1980 \mathrm{~s}$ & Oklahoma & AY739767 \\
\hline OK 10 & 1 & & Wheat & 1991 & Oklahoma & AY739769 \\
\hline SD 97039 & 1 & & Wheat & 1997 & South Dakota & AY739770 \\
\hline SD Lake & 1 & & Wheat & 1997 & South Dakota & AY739771 \\
\hline BR1 & 1 & & Wheat & 1999 & Brazil & AY739772 \\
\hline 7862 & 1 & & Wheat & 1978 & Montana & AY739773 \\
\hline OK 9 & 1 & & Wheat & 1983 & Texas & AY739774 \\
\hline ARB 1 & 2 & & Wheat & 1998 & Argentina & AY739775 \\
\hline SD Ptr 002 & 1 & & Wheat & 1997 & South Dakota & AY739778 \\
\hline SD97007 & 1 & & Wheat & 1997 & South Dakota & AY739779 \\
\hline $88-1$ & 4 & & Wheat & $1980 \mathrm{~s}$ & Canada & AY739780 \\
\hline AkCros B1 & 1 & & Wheat & 2002 & Arkansas & AY739783 \\
\hline SD97035 & 1 & & Wheat & 1997 & South Dakota & AY739785 \\
\hline Akcr B10 & 1 & & Wheat & 2002 & Arkansas & AY739789 \\
\hline AK Jac B10 & 1 & & Wheat & 2002 & Arkansas & AY739793 \\
\hline $98-9-3$ & 1 & & Wheat & 1998 & North Dakota & AY739798 \\
\hline 98D-1-20 & 1 & & Durum & 1998 & North Dakota & AY739799 \\
\hline 98D-2-27 & 1 & & Durum & 1998 & North Dakota & AY739800 \\
\hline Ptr 4B & 1 & & Wheat & 1995 & North Dakota & AY739802 \\
\hline Ptr 92 148-1-1 & 1 & & Wheat & 1992 & North Dakota & AY739804 \\
\hline 98 D-41-1 & 1 & & Durum & 1998 & North Dakota & AY739805 \\
\hline 7 & 4 & & Basin wild rye & 1997 & North Dakota & AY739807 \\
\hline 22 & 4 & & Smooth brome grass & 1997 & North Dakota & AY739808 \\
\hline NG152 & 4 & & Alti wild rye & 1997 & North Dakota & AY739811 \\
\hline USDA20 & 4 & & Needle and thread grass & 1997 & North Dakota & AY739812 \\
\hline USDA2A & 4 & & Intermediate wheat grass & 1997 & North Dakota & AY739813 \\
\hline WB5 & 4 & & Wild barley & 1997 & North Dakota & AY739863 \\
\hline MD 164 & 4 & & Smooth brome & 1997 & North Dakota & AY739814 \\
\hline MD112 & 4 & & Wild barley & 1997 & North Dakota & AY739815 \\
\hline SY3-100 & 4 & & Intermediate wheat grass & 1997 & North Dakota & AY739816 \\
\hline NG133 & 4 & & Green needlegrass & 1997 & North Dakota & AY739817 \\
\hline MD 175 & 4 & & Smooth brome grass & 1997 & North Dakota & AY739818 \\
\hline USDA10A & 4 & & Alti wild rye & 1997 & North Dakota & AY739821 \\
\hline $93-9$ & 4 & & Wild barley & 1998 & North Dakota & AY739823 \\
\hline WB4 & 4 & & Wild barley & 1997 & North Dakota & AY739862 \\
\hline Ptr 2000-5 & 1 & & Wheat & 2000 & North Dakota & AY739825 \\
\hline WB1 & 4 & & Wild barley & 1998 & North Dakota & AY739828 \\
\hline Marcia9 & 1 & & Wheat & 2002 & North Dakota & AY739834 \\
\hline $98-30-1$ & 1 & & Wheat & 1998 & North Dakota & AY739846 \\
\hline OK98-2-1 & 1 & & Wheat & 1998 & Oklahoma & AY739853 \\
\hline TSR10-2 & 1 & & Wheat & 1988 & North Dakota & AY739854 \\
\hline OK1 & 1 & & Wheat & 1982 & Oklahoma & AY739856 \\
\hline \multicolumn{7}{|l|}{ P. bromi } \\
\hline SM18A & $\mathrm{N} / \mathrm{A}$ & & Smooth brome & 1997 & Minnesota & AY739764 \\
\hline \multicolumn{7}{|l|}{ P. teres } \\
\hline ND89-19 & N/A & & Barley & 1989 & North Dakota & AY739765 \\
\hline
\end{tabular}


The presence of a large number of haplotypes in the population is not at odds with an interpretation of outcrossing, as the frequencies of these haplotypes falls within the range expected by multiplication of allelic frequencies of the most polymorphic loci, again confirming linkage equilibrium. While the level of apparent outcrossing of this fungus is sufficient to have produced gametic linkage equilibrium for most of its genes, the level of outcrossing which occurs in natural populations cannot be determined from these data. We note a close similarity between the situation in this species with the species Gibberella zeae (40). G. zeae is also a homothallic ascomycete, and it too displays a high degree of outcrossing as demonstrated by linkage equilibrium among multiple loci as well as a globally unified population.

There is no obvious connection between AFLP haplotype and pathogenic race. Both race 1 and race 4 are found to be very diverse for haplotype, while there are haplotypes shared between races 1 and 2,1 and 5, 1 and ND7, 2 and ND8, and 1 and ND8. The suggestion is that the species is very diverse for all these traits and with regular outcrossing one might expect a constant renewal of types within a population. This result agrees with that proposed by Lichter et al. (23), where although there was a substantial genomic difference between pathogenic and nonpathogenic races, it was proposed that due to lack of molecular marker polymorphism the isolates were closely related. In our study, the total population of pathogenic and nonpathogenic races (relative to wheat) appears to be closely related, and there is no natural division between different pathogenic races or between pathogenic and nonpathogenic races. This is reasonable if, as we have shown, the population is outcrossing, and it only takes the transfer of a single toxin gene to alter a race.

In work done by Aung (4), random amplified polymorphism DNA marker analysis was used to show major differentiation between pathogenic and nonpathogenic races and also lesser but significant differentiation within the pathogenic (races 1, 2, 3, 5, and 6) population. Differences between pathogenic races were shown to be between necrosis-inducing (races 1 and 2) and nonnecrosis-inducing isolates (races 3,5, and 6) as well as between race 3 and race 5 , both of which induce distinctive forms of chlorosis. No significant differences were found between races 1 and 2. In contrast to Aung (4), our work shows that pathogenic races and nonpathogenic races appear to be intercrossing as a single population in nature. The difference in results between Aung (4) and the present work in relation to the differentiation between pathogenic and nonpathogenic strains could partly be due to the sample size of each race. Our work used 21 nonpathogenic race 4 isolates and 76 pathogenic races, whereas Aung (4) used two nonpathogenic isolates and 51 pathogenic isolates, and a sample size of two may not have been large enough to

TABLE 2. Amplified fragment length polymorphism (AFLP) band loci: frequency and descriptive statistics

\begin{tabular}{|c|c|c|c|c|c|c|c|c|}
\hline AFLP band & AG-599 & AG-516 & AG-503 & AG-498 & AG-477 & AG-462 & AG-437 & AG-432 \\
\hline Positive & 0.01 & & 0.97 & 0.08 & 0.96 & 0.01 & 0.98 & \\
\hline$n e^{a}$ & 1.02 & 1.00 & 1.06 & 1.17 & 1.08 & 1.02 & 1.04 & 1.00 \\
\hline AFLP band & AG-411 & AG-398 & AG-385 & AG-360 & AG-348 & AG-322 & AG-315 & AG-308 \\
\hline Positive & 0.03 & 0.01 & 0.01 & 0.11 & 0.96 & 0.95 & & 1.00 \\
\hline AFLP band & AG-283 & AG-265 & AG-259 & AG-253 & AG-232 & AG-219 & AG-214 & AG-190 \\
\hline Positive & 0.06 & 0.98 & 0.01 & 0.02 & 1.00 & 0.03 & 1.00 & 0.70 \\
\hline Negative & 0.94 & 0.02 & 0.99 & 0.98 & . & 0.97 & & 0.30 \\
\hline ne & 1.13 & 1.04 & 1.02 & 1.04 & 1.00 & 1.06 & 1.00 & 1.71 \\
\hline $\mathrm{h}$ & 0.11 & 0.04 & 0.02 & 0.04 & 0.00 & 0.06 & 0.00 & 0.42 \\
\hline ne & 1.04 & 1.04 & 1.06 & 1.11 & 1.38 & 1.13 & 1.08 & 1.04 \\
\hline $\mathrm{h}$ & 0.04 & 0.04 & 0.06 & 0.10 & 0.27 & 0.11 & 0.08 & 0.04 \\
\hline AFLP band & AC-499 & AC-493 & AC- 480 & AC-461 & AC- -447 & AC- -428 & AC- -423 & AC-419 \\
\hline Positive & 0.91 & 0.01 & & 0.92 & 0.13 & 0.05 & & \\
\hline Negative & 0.09 & 0.99 & 1.00 & 0.08 & 0.87 & 0.95 & 1.00 & 1.00 \\
\hline ne & 1.20 & 1.02 & 1.00 & 1.04 & 1.30 & 1.11 & 1.00 & 1.00 \\
\hline $\mathrm{h}$ & 0.17 & 0.02 & 0.00 & 0.15 & 0.23 & 0.10 & 0.00 & 0.00 \\
\hline AFLP band & AC-388 & AC-383 & AC-364 & AC-355 & AC-348 & AC-326 & AC-310 & AC-299 \\
\hline Positive & 0.95 & 0.98 & 0.91 & 0.91 & 0.01 & 0.19 & 0.76 & 0.02 \\
\hline Negative & 0.05 & 0.02 & 0.09 & 0.09 & 0.99 & 0.81 & 0.25 & 0.98 \\
\hline
\end{tabular}

${ }^{\mathrm{a}}$ ne $=$ effective number of alleles (Kimura and Crow [19]).

${ }^{\mathrm{b}} \mathrm{h}=$ genetic diversity index (27). 
identify significant outcrossing within the population. In our study, all but three of our pathogenic races were necrosis-producing isolates and therefore this set of isolates would neither be sufficient to detect differences between necrosis- and nonnecrosisproducing isolates nor between races producing different forms of chlorosis.

In addition, the data presented here do not show clear divisions between different species of the genus Pyrenophora. Sequence analysis of the ITS region fails to separate $P$. tritici-repentis from $P$. bromi (although there is some differentiation between $P$. triticirepentis and $P$. teres). Also, in one case, AFLP similarity is greater between a $P$. tritici-repentis isolate $(P \operatorname{tr} 2000-5)$ and a $P$. teres isolate (ND89-19) than between the same P. tritici-repentis isolate and other isolates from the same species. While, in the majority of cases, there is clear differentiation between the species on the AFLP level, the number of shared bands among all three species suggests close genetic affinities.

In a previous study using ITS sequence to investigate the genus Pyrenophora, Zhang and Berbee (41) used two isolates of P. triticirepentis and a single isolate each of $P$. bromi and $P$. teres. This work showed that using ITS sequence, $P$. tritici-repentis and $P$. bromi grouped together and $P$. teres was also closely related. Our results are compatible with those of Zhang and Berbee (41), with the added observation that our ITS data do not separate $P$. bromi and $P$. tritici-repentis, but rather we find that the ITS sequences from some $P$. tritici-repentis isolates are more similar to the P. bromi ITS sequences (both our own and those previously published) than they are to other $P$. tritici-repentis-derived ITS sequences.

The work presented here has laid the foundation for future studies by providing valuable information on the genetic diversity of the worldwide population of $P$. tritici-repentis. These studies may include a larger more diverse study incorporating more isolates from all continents and wheat growing regions of the world. This study has also revealed that a comparative analysis of other cereal pathogen species of the genus Pyrenophora should be undertaken.

\section{ACKNOWLEDGMENTS}

This research was supported by USDA CRIS project 5442-22000-03000D. We thank D. Holmes for technical assistance and W. Bockus, R. Hunger, L. Lamari, Y. Jin, and J. Sarova for the isolates from Kansas, Oklahoma, Canada, South Dakota, and The Czech Republic, respectively.

\section{LITERATURE CITED}

1. Ali, S., and Francl, L. J. 2003. Population race structure of Pyrenophora tritici-repentis prevalent on wheat and non-cereal grasses. Plant Dis. 87:418-422.

2. Ali, S., and Francl, L. J. 2003. A new race of Pyrenophora tritici-repentis from Brazil. Plant Dis. 86:1050.

3. Aljanabi, S. M., and Martinez, I. 1997. Universal and rapid salt-extraction of high quality genomic DNA for PCR-based techniques. Nucleic Acids Res. 25:4692-4693.

4. Aung, T. S. G. 2001. Molecular polymorphism and virulence in Pyrenophora tritici-repentis. MS thesis. The University of Manitoba.

5. Ballance, G. M., Lamari, L., and Bernier, C. C. 1989. Purification and characterization of a host selective toxin from Pyrenophora tritici-repentis. Physiol. Mol. Plant Pathol. 35:203-213.

6. Brown, D. A., and Hunger, R. M. 1993. Production of a chlorosisinducing, host-specific, low-molecular weight toxin by isolates of Pyrenophora tritici-repentis, cause of tan spot of wheat. J. Phytopathol. 137:221232.

7. Ciuffetti, L. M., and Touri, R. P. 1999. Advances in the characterization of the Pyrenophora tritici-repentis-wheat interaction. Phytopathology 89:444-449.

8. Ciuffetti, L. M., Touri, R. P., and Gaventa, J. M. 1997. A single gene encodes a selective toxin causal to the development of tan spot of wheat. Plant Cell 9:135-144.

9. Crow, J. F., and Kimura, M. 1970. An Introduction to Population Genetics Theory. Harper and Row, New York.
10. De Wolf, E. D., Effertz, R. J., Ali, S., and Francl, L. J. 1998. Vistas of tan spot research. Can. J. Plant Pathol. 20:349-370.

11. Diedicke, H. 1902. Uber den Zusammenhang zwischen Pleospora-und Helminthosporium-Arten. Centralblatt für Bakteriologie und Parasitenkunde Jena, Abt 9:317-329.

12. Dreschler, C. 1923. Some graminicolous species of Helminthosporium I. J. Agric. Res. 24:641-740.

13. Effertz, R. J., Meinhardt, S. W., Anderson, J. A., Jordahl, J. G., and Francl, L. J. 2002. Identification of a chlorosis-inducing toxin from Pyrenophora tritici-repentis and the chromosomal location of an insensitivity locus in wheat. Phytopathology 92:527-533.

14. Felsenstein, J. 2004. PHYLIP (Phylogeny Inference Package), version 3.6b. Department of Genetics, University of Washington, Seattle.

15. Higgins, D., Thompson, J., Gibson, T., Thompson, J. D., Higgins, D. G., and Gibson, T. J. 1994. CLUSTAL W: Improving the sensitivity of progressive multiple sequence alignment through sequence weighting, position-specific gap penalties and weight matrix choice. Nucleic Acids Res. 22:4673-4680.

16. Hosford, R. M., Jr. 1971. A form of Pyrenophora trichostoma pathogenic to wheat and other grasses. Phytopathology 61:28-32.

17. Hosford, R. M., Jr. 1982. Tan spot-developing knowledge 1902-1981, Virulent races and wheat differentials, methodology, rating systems, other leaf diseases, literature. Pages 1-24 in: Tan Spot of Wheat and Related Diseases Workshop. R. M. Hosford Jr., ed. North Dakota Agric. Exp. Station, Fargo.

18. Jurgenson, J. E., Bowden, R. L., Zeller, K. A., Leslie, J. F., Alexander, N. J., and Plattner, R. D. 2002. A genetic map of Gibberella zeae (Fusarium graminearum). Genetics 160:1452-1460.

19. Kimura, M., and Crow, J. F. 1964. The number of alleles that can be maintained in a finite population. Genetics 49:725-738.

20. Lamari, L., and Bernier, C. C. 1989. Virulence of isolates of Pyrenophora tritici-repentis on 11 wheat cultivars and cytology of the differential host reaction. Can. J. Plant Pathol. 11:284-290.

21. Lamari, L., Sayoud, R., Boulif, M., and Bernier, C. C. 1995. Identification of a new race in Pyrenophora tritici-repentis: Implications for the current pathotype classification system. Can. J. Plant Pathol. 17:312-318.

22. Lamari, L., Strelkov, S. E., Yahyaoui, A., Orabi, J., and Smith, R. B. 2003. The identification of two new races of Pyrenophora tritici-repentis from the host center of diversity confirms a one-to-one relationship in tan spot of wheat. Phytopathology 93:391-396.

23. Lichter, A., Gaventa, J. M., and Ciuffetti, L. M. 2002. Chromosome-based molecular characterization of pathogenic and non-pathogenic wheat isolates of Pyrenophora tritici-repentis. Fungal Genet. Biol. 37:180-189.

24. Manning, V. A., Pandelova, I., and Ciuffetti, L. M. 2002. A race for a novel host selective toxin. (Abstr.) Phytopathology 92(suppl.):S51.

25. Martinez, J. P., Ottum, S. A., Ali, S., Francl, L. J., and Ciuffetti, L. M. 2001. Characterization of the ToxB gene from Pyrenophora triticirepentis. Mol. Plant-Microbe Interact. 14:675-677.

26. Meinhardt, S., Ali, S., Ling, H., and Francl, L. 2003. A new race of Pyrenophora tritici-repentis that produces a putative host-selective toxin. Pages 117-121 in: Proc. Fourth International Wheat Tan Spot and Spot Blotch Workshop. J. B. Rasmussen, T. L. Friesen, and S. Ali, eds. North Dakota Agric. Exp. Stn., Fargo, ND.

27. Nei, M. 1978. Estimation of average heterozygosity and genetic distance from a small number of individuals. Genetics 89:583-590.

28. Nisikado, Y. 1928. Preliminary notes on yellow spot diseases of wheat caused by Helminthosporium tritici-vulgaris Nisikado. Inst. Agric. Biol. 4:103-109.

29. Orolaza, N. P., Lamari, L., and Balance, G. M. 1995. Evidence of a host specific chlorosis toxin from Pyrenophora tritici-repentis, the causal agent of tan spot of wheat. Phytopathology 85:1282-1287.

30. Pearson, W. R., and Lipman, D. J. 1988. Improved tools for biological sequence comparison. PNAS 85:2444-2448.

31. Strelkov, S. E., and Lamari, L. 2003. Host-parasite interaction in tan spot [Pyrenophora tritici-repentis] of wheat. Can. J. Plant Pathol. 25:339-349.

32. Strelkov, S. E., Lamari, L., Ballance, G. M. 1999. Characterization of a host-specific protein toxin (Ptr ToxB) from Pyrenophora tritici-repentis. Mol. Plant-Microbe Interact. 12:728-732.

33. Tomás, A., and Bockus, W. W. 1987. Cultivar specific toxicity of culture filtrate of Pyrenophora tritici-repentis. Phytopathology 77:1337-1366.

34. Tomás, A., Feng, G. H., Reeck, G. R., Bockus, W. W., and Leach, J. E. 1990. Purification of a cultivar-specific toxin from Pyrenophora triticirepentis, causal agent of tan spot of wheat. Mol. Plant-Microbe Interact. 3:221-224.

35. Tuori, R. P., Wolpert, T. J., and Ciuffetti, L. M. 1995. Purification and immunological characterization of toxic components from cultures of Pyrenophora tritici-repentis. Mol. Plant-Microbe Interact. 8:41-48.

36. Vanterpool, T. C. 1963. Pink and smudge pink discoloration of wheat seed associated with the yellow leaf spot disease (Drechslera tritici-repentis). Proc. Can. Phytopathol. Soc. 30:19-20. 
37. Vos, P., Hogers, R., Bleeker, M. Reijans, M., Van-De-Lee, T., Hornes, M., Frijters, A., Pot, J., Peleman, J., Kuiper, M., and Zabeau, M. 1995. AFLP: A new technique for DNA fingerprinting. Nucleic Acids Res. 23:4407-4414.

38. White, T. J., Bruns, T., Lee, S., and Taylor, J. 1990. Amplification and direct sequencing of fungal ribosomal DNA for phylogenetics. Pages 315322 in: PCR Protocols: A Guide to the Methods and Applications. M. A. Innis, D. H. Gelfand, J. J. Sninsky, and T. J. White, eds. Academic Press, San Diego, CA.

39. Yeh, F. C., and Boyle, T. J. B. 1997. Population genetic analysis of codominant and dominant markers and quantitative traits. Belgian J. Bot.
129:157.

40. Zeller, K. A., Bowden, R. L., and Leslie, J. F. 2004. Population differentiation and recombination in wheat scab populations of Gibberella zeae from the United States. Mol. Ecol. 13:563-571.

41. Zhang, G., and Berbee, M. L. 2001. Pyrenophora phylogenetics inferred from ITS and glyceraldehyde-3-phosphate dehydrogenase gene sequences. Mycologia 93:1048-1063.

42. Zhang, H. F., Francl, L. J., Jordahl, J. G., and Meinhardt, S. W. 1997. Structural and physical properties of a necrosis-inducing toxin from Pyrenophora tritici-repentis. Phytopathology 87:154-160. 